\title{
PEMULIHAN TRAUMA ANAK-ANAK KORBAN GEMPA DI KOTA PALU MELALUI MENDONGENG
}

\author{
Syamsuddin \\ Program Studi Bahasa dan Sastra Indonesia, Fakultas Sastra, Universitas Alkhairaat \\ syam.50TV@gmail.com
}

\begin{abstract}
ABSTRAK
Permasalahan dalam penelitian ini adalah (1) Apa strategi dan teknik yang dilakukan dalam mendongeng pada anak-anak korban gempa di Palu, (2) Apa saja yang menjadi kendala selama ini dalam kegiatan mendongeng di Kota Palu. Penelitian dilakukan di Kota Palu dengan pertimbangan (1) Kota Palu merupakan daerah terdampak gempa bumi paling parah dan banyak korbannya anak-anak. (2) Banyak anak-anak korban bencana yang butuh penanganan serius dalam proses pemulihan trauma baik yang putus sekolah maupun yang lanjut sekolah. Hasil penelitian menunjukkan: (1) Mendongeng menjadi salah satu metode pendekatan yang efektif dalam memulihkan trauma anak-anak korban gempa di Kota Palu. (2) Pendongeng di Kota Palu masih sangat kurang sementara jumlah anak-anak yang butuh pendampingan psikologis cukup banyak. (3) Masih minimnya lembaga di tingkat lokal yang fokus di kegiatan mendongeng.
\end{abstract}

Kata Kunci : Pemulihan trauma, Mendongeng, Anak-anak.

\begin{abstract}
The problems in this study are (1) What strategies and techniques are used in storytelling in children affected by the earthquake in Palu, (2) What are the obstacles so far in storytelling activities in Palu City. The study was conducted in Palu City with the following considerations: (1) Palu City was the area most severely affected by the earthquake and many had casualties. (2) Many disaster victims' children need serious treatment in the process of recovering from trauma both those who have dropped out of school or those who have gone to school. The results showed: (1) Storytelling became one of the effective approach methods in recovering the trauma of children affected by the earthquake in Palu City. (2) Storytellers in Palu City are still lacking while there are quite a number of children who need psychological assistance. (3) The lack of institutions at the local level that focus on storytelling activities.
\end{abstract}

Keywords : Trauma Healing, Storytelling, Childrens

\section{PENDAHULUAN}

Banyaknya gempa bumi yang terjadi di Indonesia beberapa tahun terakhir ini menunjukkan betapa Indonesia memiliki resiko yang tinggi akan bencana tersebut. Bencana gempa bumi memiliki kualitas sebagai pengalaman traumatis yang bisa berdampak munculnya gangguan stres pasca trauma (Stres Pascatrauma) terutama pada anak-anak dan remaja. Resiko ini muncul sebagai dampak bencana yang menyengsarakan individu dan keluarga, kehilangan anggota keluarga yang dikasihi serta hancurnya sistem masyarakat.

Berdasarkan penelitian sebelumnya menunjukkan bahwa anak-anak memiliki resiko yang terhadap Stres Pascatrauma (Doherty dalam Pynoos 2001). Mulyadi (2004) juga mengemukakan bahwa bencana yang datang silih berganti dapat berisiko untuk melahirkan generasi-generasi yang emosional, menyelesaikan masalah dengan 
jalan pintas serta rentan terhadap frustasi. Pendekatan yang khas sangat mutlak diperlukan untuk memberikan pendampingan pada anak korban bencana agar pulih dari trauma.

Pemulihan trauma kepada anak-anak pasca bencana bertujuan untuk mencegah munculnya gangguan psikologis yang lebih berat. Selain itu pemberian pelayanan psikologis yang intensif baik secara individu, kelompok maupun komunitas bagi korban bencana dapat meningkatkan ketahanan (resiliensi) sehingga kelak anak-anak menjadi lebih tangguh dan siap menghadapi permasalahan yang ada. Namun proses pemulihan ini membutuhkan waktu yang tidak instan dan harus melibatkan sumber daya yang memadai dan profesional seperti psikolog, pekerja sosial, pekerja kreatif, relawan dan lain-lain.

Salah satu metode pendekatan yang selama ini digunakan untuk memulihkan traumatik korban gempa khususnya anakanak adalah dengan mendongeng. Sebagai media untuk pemulihan trauma,mendongeng diketahui sudah menjadi sebuah budaya dan berpengaruh secara signifikan terhadap perkembangan kesehatan seseorang khususnya anak-anak. Selama mendongeng, anak-anak merasa sangat rileks dan terbawa ke dalam latar cerita yang dibawakan karena ketika mereka mendengarkan cerita, masingmasing anak memiliki imajinasi masingmasing terhadap tokoh dan latar dari cerita yang dibawakan.

Mendongeng merupakan sebuah seni yang menggunakan bahasa, vokal, dan gerak tubuh untuk mengungkapkan elemen maupun gambaran sebuah cerita kepada penonton secara langsung. Menurut Pelowski dalam Takwin (2005:3-4), mendongeng adalah seni atau keterampilan pengisahan cerita dari naskah puitis dan atau prosa, sebagai sesuatu yang ditampilkan atau diarahkan satu orang di hadapan pemirsa, cerita-cerita yang dikisahkan dapat disampaikan dalam bentuk tuturan kata, didendangkan atau dinyanyikan, dengan atau tanpa iringan musik, gambar, dan atau pelengkap lainnya serta dapat dipelajari dari sumber lisan, tertulis atau rekaman dan salah satu tujuan dari mendongeng ini adalah sebagai hiburan.
Pada dasarnya mendongeng merupakan kegiatan sederhana yang dapat dilakukan oleh siapapun tanpa mengenal waktu dan tempat. Mendongeng merupakan media terbaik yang bisa dilakukan seseorang untuk mewarisi gagasam-gagasan, pola pikir, dan adat istiadat dari sebuah masyarakat. Selain itu mendongeng juga dapat dijadikan sebagai media untuk bertukar pengalaman dan cerita kepada anak-anak. Di saat kita membertahu sesuatu, kita menunjukkan perasaan kita yang terdalam, nilai-nilai yang ada pada cerita yang membuat anak-anak menjadi terbuka terhadap nilai-nilai yang kita bawakan dalam dongeng.

Mendongeng memiliki banyak manfaat bagi anak-anak terutama dalam meningkatkan rasa kebersamaan karena saat mendongeng terjadi interaksi antara sesama anak. Aktivitas yang dilakukan secara bersamaan dengan sesama anak-anak tentunya akan membantu mempermudah anak-anak tersebut lebih dekat dengan keluarga dan anak-anak yang lain, membuat mereka melupakan ketakutan akan bencana dan merasa terhibur dengan dongeng yang dibawakan.(Greene,1996).

Menurut Bunanta (2009), mendongeng memiliki beberapa fungsi, antara lain dapat menjalin hubungan kedekatan antara anak dengan orang tua, memberikan pengetahuan baru, memaksimalkan kecerdasan anak, melatih anak tentang memberikan perhatian kepada orang lain, melatih dan menambah perbendaharaan kata pada anak, menanamkan nilai-nilai moral yang terkandung dalam cerita serta menumbuhkan moral positif pada anak.

Dari berbagai hasil penelitian diketahui mendongeng ternyata tidak hanya bersifat menghibur tapi juga dapat memperngaruhi perkembangan moral dan tumbuh kembang seorang anak. Mendongeng juga dapat digunakan sebagai metode untuk memulihkan trauma pada anak-anak korban bencana di berbagai daerah di Indonesia, termasuk pasca gempa bumi, likuifaksi dan tsunami di Kota Palu, 28 September 2018 lalu.Anak-anak yang menjadi korban bencana gempa bumi, likuifaksi dan tsunami di Kota Palu jumlahnya ribuan jiwa dan butuh penanganan serius. 
Kondisi yang dialami anak-anak korban gempa bumi di Kota Palu tersebut mengundang keprihatinan berbagai kalangan baik dari pemerintah, psikolog, organisasi pemerhati anak hingga relawan yang datang dari berbagai daerah di Indonesia bahkan dari luar negeri. Mereka memberikan dukungan dan perhatian ekstra kepada anak-anak butuh tidak hanya terkait makanan dan obat-obatan tapi juga pemulihan trauma. Sejumlah komunitas dan relawan pun membantu pemulihan tersebut melalui metode mendongeng, salah satunya Kampung Dongeng. Upaya tersebut dilakukan sejak beberapa minggu pasca gempa bumi berkekuatan 7,4 skala richter yang tidak hanya menyebabkan tsunami dan likuifaksi tapi juga penurunan tanah (down lift).

Dalam menjalankan aktivitasnya, pendongeng dari Komunitas Kampung Dongeng ini tidak hanya menyasar anak-anak yang tengah duduk di bangku pendidikan formal tapi anak-anak putus sekolah dan usia dini terutama yang tinggal di hunian sementara (huntara) yang tersebar di delapan kecamatan di Kota Palu. Mereka keliling dari satu huntara ke huntara lain meski jumlah anak-anak yang diajar tak tentu.

Namun perlu diketahui, mendongeng sebagai metode untuk memulihkan trauma pada anak-anak berbeda dengan terapi lainnya dalam berbagai aspek. Pertama, terapi dengan mendongeng sangat bergantung pada intuisi, karena dengan mendongeng terapi bergantung kepada pikiran bawah sadarnya. Pelatihan kepekaan terhadap alam bawah sadar ini sangat penting dilakukan dan merupakan inti dari proses pemulihan trauma. Kedua, mendongeng memiliki nilai spritual yakni dapat dengan mudah menghubungkan perasaan serta pikiran antara audiens dan pendongengnya dengan cepat. Kejujuran, berbicara dari hati, membuka telinga, mata, hati dan pikiran anak adalah inti dari mendongeng. Mendongeng digunakan sebagai terapi ini memberikan suasana menyenangkan dan memberikan hiburan kepada anak, bukan memberikan kesan sakit dan menyeramkan jika dibandingkan dengan kata terapi pada umumnya, sehingga anak tidak perlu merasa takut dan orang tua juga tidak perlu memaksa anak untuk mengikuti terapi dengan mendongeng ini. Melalui metode mendongeng, interaksi antara pendongeng dengan anak dapat dengan mudah terjalin tanpa harus ada rasa saling keterpaksaan dari pihak anak yang mengalami trauma.

Ketika menjadikan dongeng sebagai terapi maka tentunya harus memperhatikan kondisi anak-anak apakah mereka sudah terlihat senang atau mampu menerima keadaannya saat itu atau tidak.Hal ini diharapkan dapat mempengaruhi pola pikir dan cara pandang mereka. Dengan upaya tersebut diharapkan anak-anak korban bencana alam akan menjadi lebih rileks dan santai. Kegiatan dongeng ini kemudian membuat anak-anak merasa terhibur dan lebih tenang dan senang sehingga kepanikan dan kecemasannya perlahan-lahan berkurang.

Kondisi inilah yang menjadi tujuan utama dari komunitas Kampung Dongeng yakni bagaimana memberikan pendampingan psikologis melalui pemulihan kembali trauma anak-anak korban bencana gempa bumi, likuifaksi dan tsunami di Kota Palu. Bahkan tidak hanya di Kota Palu tapi seluruh wilayah yang terdampak gempa tanggal 28 September 2018 lalu seperti Kabupaten Sigi, Kabupaten Donggala dan Kabupaten Parigi Moutong.

Untuk mewujudkan tujuan tersebut, tentu bukan hal yang mudah dan membutuhkan waktu yang agak lama. Mengingat peristiwa besar yang menyebabkan korban jiwa dan materi yang cukup besar sehingga meninggalkan trauma yang mendalam.

\section{METODE PENELITIAN}

Penelitian yang dilakukan adalah penelitian kualitatif dengan pendekatan life story. Menurut Wesbrook (1997: 144) pendekatan ini digunakan karena pendekatan kualitatif cocok digunakan untuk penelitian dimana hal tersebut sudah diketahui hanya sedikit sekali sementara hal yang ingin diketahui cukup nyata dan penting. Pendekatan penelitian ini mengungkapkan situasi sosial tertentu dengan mendeskripsikan kenyataan secara benar, dibentuk oleh kata-kata berdasarkan teknik pengumpulan dan analisis data yang relevan yang diperoleh dari situasi yang alamiah. 
Untuk menjawab permasalahan dan menguji hipotesis penelitian digunakan analisis kualitatif dengan memaparkan hasil penelitian secara deskriptif. Adapun tahapantahapan analisis data tersebut yakni: penyusunan satuan atau koding data, kategorisasi atau pengelompokan data, interpretasi/penafsiran makna data dan penarikan kesimpulan dan saran-saran hasil penelitian.

\section{HASIL DAN PEMBAHASAN}

Mendongeng merupakan sebuah seni yang menggunakan bahasa, vokal, dan gerak tubuh untuk mengungkapkan elemen maupun gambaran sebuah cerita kepada penonton secara langsung. Menurut Pelowski dalam Takwin (2005:3-4), mendongeng adalah seni atau keterampilan pengisahan cerita dari naskah puitis dan atau prosa, sebagai sesuatu yang ditampilkan atau diarahkan satu orang di hadapan pemirsa, cerita-cerita yang dikisahkan dapat disampaikan dalam bentuk tuturan kata, didendangkan atau dinyanyikan, dengan atau tanpa iringan musik, gambar, dan atau pelengkap lainnya serta dapat dipelajari dari sumber lisan, tertulis atau rekaman dan salah satu tujuan dari mendongeng ini adalah sebagai hiburan.

Secara umum, dongeng memiliki beberapa manfaat yang bisa dipetik oleh orang-orang yang terlibat di dalamnya baik itu sang pendongeng maupun mereka yang menjadi audiensnya. Dongeng memberi kesempatan bagi pendongeng dan audiensnya untuk mengenali diri mereka masing-masing. Melalui dongeng, mereka akan memperoleh suatu pengalaman tanpa harus mengalaminya sendiri secara langsung. Menurut Mal dalam bukunya The Power of Storytelling (2008), ada lima manfaat mendongeng kepada anak, yakni 1) merangsang kekuatan berfikir, 2) sebagai media yang efektif, 3) mengasah kepekaan anak terhadap bunyi-bunyian, 4) menumbuhkan minat baca dan 5) menumbuhkan rasa empati.

Kegiatan mendongeng sesungguhnya tidak hanya bersifat hiburan tapi juga memiliki tujuan. Menurut Priyono Kusumo (2008), tujuan utama mendongeng adalah memperkaya batin anak dan menstimulir reaksi sehat atasnya. Melalui mendongeng, kita dapat melakukan kontak batin dan sekaligus berkomunikasi dengan anak sehingga membina hubungan yang baik.

King dan Down (2001) mengatakan bahwa selain memberikan kesempatan untuk mengenali kehidupan di luar, pengalaman hidupnya dan mengenali diri sendiri, dongeng seperti halnya berbentuk cerita yang juga dapat memberikan motivasi kepada pendongeng dan audiensnya. Cerita tentang kesuksesan dalam bentuk biografi merupakan contoh yang paling nyata dari sebuah cerita yang dapat memberi inspirasi kepada orangorang untuk melangkah maju dan meraih kesuksesan dalam hidup mereka masingmasing.

Mendongeng juga mempunyai nilai kegunaan dalam membina hubungan sosial, terutama sebagai sarana komunikasi dengan audiensnya. Dapat dilihat bahwa kegiatan bercerita membuka kesempatan bagi individu untuk membangun hubungan dengan orang lain. Self-disclosure yang dikatakan sebagai salah satu kunci pembangun hubungan dengan orang lain, dapat dilakukan dengan mendongeng. Dengan mendongeng, pendongeng dapat membuka akses informasi dirinya untuk orang lain. Bila hal ini tidak terjadi dalam hubungan interpersonal maka akan ada jarak diantara kedua individu tersebut (Fisher dan Adams, 1994).

Dalam proses mendongeng, Bunanta (2005) menyebutkan ada dua teknik yang dapat digunakan yakni teknik nread aloud dan teknik mendongeng tanpa teks (storytelling)

a) Teknik read aloud

Teknik read aloud merupakan sebuah teknik yang menyampaikan cerita dengan menggunakan media buku, dan dilakukan dengan cara membacakan buku tersebut di hadapan audience. Dengan teknik ini pendongeng dapat duduk di depan audience pendongeng dapat duduk di depan audience dan apabila audience hanya terdiri dari beberapa orang saja maka pendongeng dapat duduk di tengahtengah audience. Hal yang harus dipertimbangkan dalam teknik ini adalah terkait dengan jumlah audience. Jika jumlah audience terlalu banyak maka pendongeng tidak dapat menjangkau mereka semua sehingga audience tidak dapat melihat dengan jelas buku yang 
dibacakan baik gambar ataupun bentuk tulisannya.

b) Mendongeng tanpa teks (storytelling) Pengunaan teknik mendongeng ini memberikan ruang kepada pendongeng untuk melakukan improvisasi dan berkreasi dalam menyampaikan cerita yang didongengkan serta memicu anak untuk berimajinasi serta berfantasi dengan pikiran mereka. Namun, pada waktu mendongeng sebaiknya anak bukan pada cerita, tetapi lebih kepada penampilan pendongeng. Hal ini akan berakibat pada proses penerimaan anak terhadap pesan atau nilai dari cerita yang dibawakan.

\section{Mendongeng Sebagai Terapi Pemulihan Trauma}

Mendongeng untuk pemulihan trauma atau yang biasa disebut dengan dongeng terapeutik dianggap para terapis sebagai metode komunikasi untuk menyelesaikan masalah psikologis yang diderita anak-anak pasca terjadinya bencana di lingkungan mereka. Selain itu ada juga yang menyebut metode ini sebagai terapi mendongeng yang memiliki arti sebagai sebuah metode yang dipakai untuk mempengaruhi orang dengan membacakannya cerita yang berguna untuk menyelesaikan masalah pribadi mereka. Penggunaan metode mendongeng ini telah dideskripsikan sebagai metode yang memiliki orientasi pendekatan pada anak yang sangat kuat dan memiliki kekuatan yang kuat dalam memberikan pengertian dan pemahaman masalah anak dengan trauma yang dihadapinya karena mendongeng dapat memberikan pengajaran, perbandingan, mempengaruhi dan membangun kepercayaan diri sebaik-baiknya seperti kita mengenal lingkungan sosial yang unik. Selain itu, mendongeng juga dipercaya sebagai media untuk membentuk karakter yang kuat pada anak dan juga dapat menyehatkan tubuh baik kesehatan jasmani maupun rohani.

Terapi mendongeng ini tercipta berdasarkan filosofi dari perbedaan budayabudaya dan beberapa model psikoterapi lainnya. Metode mendongeng ini menggabungkan prosedur psikoterapi yang rumit dengan interaksi antara pendongeng dengan audiens. Cerita-cerita yang didongengkan dengan tepat akan mengaktifkan alam bawah sadar audiens yang mengalami trauma. Terapi dengan mendongeng ini dikatakan berhasil apabila audiens yang mengalami trauma dapat mengenali dan memahami unsur-unsur yang terdapat di dalam dongeng dan mencapai hasil yang diinginkan yaitu pulih dari trauma yang dialaminya.

Penggunaan mendongeng sebagai media pemulihan trauma diketahui telah menjadi sebuah budaya dan mempengaruhi secara cepat perkembangan kesehatan seseorang. Selama mendongeng, audiens merasa sangat rileks dan terbawa ke dalam latar cerita yang dibawakan karena ketika mereka mendengarkan cerita, masing-masing audiens memiliki imajinasi masing-masing terhadap tokoh dan latar dari cerita yang dibawakan.

\section{Kendala Yang Dihadapi Pendongeng Dalam Pemulihan Trauma}

Dalam melakukan kegiatan mendongeng, tentunya pendongeng tidak selamanya mendapat respon serius dari kelompok atau anak-anak korban gempa. Ada beberapa kendala yang dihadapi para pendongeng khususnya di Kota Palu.

a) Pendongeng belum semuanya memahami bahasa dan budaya di lokasi yang menjadi sasaran kegiatan. Padahal pesan atau cerita akan lebih cepat diterima atau dipahami anak-anak khususnya yang putus sekolah jika menggunakan bahasa daerah dan menonjolkan kearifan lokal. Sebenarnya cukup banyak cerita rakyat maupun kearifan lokal lainnya di lembah Palu yang menarik untuk dijadikan materi dongeng.

b) Pendongeng sebagian besar masih memiliki aktivitas atau kesibukan lain khususnya yang berasal dari luar Kota Palu sehingga kesulitan mengatur jadwal untuk mendongeng kepada anak-anak. Sementara pendongeng yang berasal dari Kota Palu masih sangat terbatas bahkan bisa dibilang sangat langka.

c) Masih kurangnya ilmu pengetahuan tentang dongeng yang memadai dimiliki pendongeng karena mereka bukanlah berasal dari latar belakang pengetahuan mendongeng. Umumnya materi yang diberikan pendongeng kepada anak-anak selama ini diperoleh dari pelatihanpelatihan. 


\section{KESIMPULAN}

Mendongeng sebagai salah satu metode pendekatan pemulihan trauma anakanak korban gempa khususnya di Kota Palu sesungguhnya tidaklah sulit dilakukan oleh siapa saja tanpa memiliki kompetensi atau sertifikat khusus sebagai pendongeng. Hanya memang untuk menjadi pendongeng dibutuhkan kemauan dan kesabaran apalagi yang dihadapi adalah anak-anak.

Strategi yang digunakan untuk mendongeng untuk memulihkan trauma sebenarnya sama saja dengan proses mendongeng untuk menghibur anak-anak pada umumnya. Namun perbedaan antara mendongeng biasa dan mendongeng untuk pemulihan trauma terletak pada cerita, audiens dan intensitas pendekatan yang dilakukan kepada anak yang trauma. Strategi tersebut dimulai dari kriteria pemilihan cerita, alat peraga yang digunakan serta pada kegiatan setelah mendongeng yang dilakukan oleh informan sedangkan untuk teknik yang digunakan ada dua yakni mendongeng dengan menggunakan buku atau read aloud dan mendongeng tanpa teks atau storytelling. Kedua teknik ini digunakan secara bergantian dan disesuaikan dengan kondisi dan keadaan lokasi serta anak-anak yang mengalami trauma.

Dalam kegiatan mendongeng sering muncul kendala namun bisa teratasi melalui komunikasi dan sosialisasi secara rancangan kegiatan baik kepada orang tua, koordinator posko pengungsian serta pihak terkait di lokasi bencana. Selain itu tentunya butuh dukungan dan kerjasama tim yang baik.

\section{SARAN}

Berdasarkan kesimpulan tersebut di atas, terdapat beberapa saran yang perlu ditindaklanjuti, antara lain:

1) Perlunya kepekaan orang tua dalam melihat perubahan sikap pada diri anak pasca bencana

2) Dalam kegiatan pemulihan trauma khususnya melalui mendongeng harus melibatkan semua pihak agar kegiatan tersebut bisa berkesinambungan.

3) Pendongeng harus memiliki teknik, kreatif dan inovatif dalam menyampaikan dongeng kepada anak-anak agar tertarik dan tidak bosan.

4) Dalam kegiatan mendongeng, pendongeng juga sebaiknya memberikan nilai-nilai keagamaan kepada anak-anak korban gempa agar mereka faham jika segala musibah yang terjadi karena kehendak-Nya.

\section{DAFTAR PUSTAKA}

Asfandiyar, Andi Yudha. (2007). Cara Pintar Mendongeng. Bandung : Dar! Mizan

Bunanta, Murti. (2005). Buku, Dongeng dan Minat Membaca. Jakarta: Pustaka Tangga.

Cahyo (2009). Membantu Anak Menghadapi Situasi Pasca Gempa. Jakarta: Yayasan Pulih.

Cundiff, Ruby Ethel \& Barbara Webb. (1957). Story-telling for you: a handbook of help for story-tellers everywhere. Ohio: Antioch.

Farid, Mochammad Ariyo. (2004). Kegiatan Mendongeng Orang Tua di Jabodetabek. Depok : Fakultas Ilmu Pengetahuan Budaya, Universitas Indonesia.

Greene, Ellin.(1996). Storytelling: Art and techhnique. London. Libraries Unlimited.

Hidayat, M.Zein, R.Yuli Budirahayu dan Christina Fong. (2010). Buku Panduan Dongeng Terapeutik: Hipnoterapi Untuk Anak Yang Sering Cemas dan Takut. Jakarta: Tiga Kelana.

Koentjaraningrat. (1993). Metode-metode Penelitian Masyarakat. Jakarta: Gramedia.

Kharismawan, Kuriake. (2008). Panduan Program Psikososial Pasca Bencana. Semarang: Center For Trauma Recovery Unika Soegijapranata. 
Lesmana, Maman (2010). Teknik Mendongeng Untuk Orang Tua/Guru dan Kumpulan Dongeng Untuk Anak. Materi untuk pelatihan pengabdian pada masyarakat. Depok. Fakultas Ilmu Pengetahuan Budaya Universitas Indonesia.

Mal. (2008). The power of storytelling: Kekuatan dongeng terhadap pembentukan karakter anak. Depok: Luxima

Novalita. (2009). Kegiatan Mendongeng sebaGai Upaya menumbuhkan Minat Baca Pada Anak: Studi Kasus di Taman Baca Keluarga Pelangi. Depok: Fakultas Ilmu Pengetahuan Budaya, Universitas Indonesia.

Priyono, Kusumo. (2008). Terampil Mendongeng. Jakarta: Ars-Grasindo.

Pellowski, A. (1997). The World of Storytelling.New York: R.R.Bowker.

Soraya, Irani. (2008). Studi Awal Mengenai Dongeng Sebagai Metode Terapi
Untuk Mengurangi Dampak Psikologis.academia.edu/333268253/

STUDI AWAL MENGENAI DONGENG SEBAGAI METODE TERAPI UNTUK MENGURANGI DAMPAK PSIKOLOGIS diakses 15 Nopember 2019.

Paramitha, Suci. (2011). Mendongeng Sebagai Metode Pemulihan Trauma Pada Anak-Anak di Daerah Pasca Bencana: Sebuah Analisis Life History Pustakawan Pendongeng http://lib.ui.ac.id/file?file=digital/2023 4590-S572-

Mendongeng\%20sebagai.pdf diakses 17 Nopember 2019. 